\title{
Synthesis and Physico-chemical Characterization of Nanohybrid Materials Based on Isonicotinic Acid Hydrazide
}

\author{
ELENA ARIELA BANU14, LETITIA DOINA DUCEAC ${ }^{2,5 *}$, GETA MITREA ${ }^{1,6 *}$, MADALINA IRINA CIUHODARU3,7*, \\ DANIEL A LUMINITA ICHIM ${ }^{2,8}$, IRINA MIHAELA CIOMAGA ${ }^{3,5}$, ROXANA ELENA BOGDAN GOROFTEI ${ }^{1,4}$, \\ MARCU CONSTANTIN ${ }^{1,9}$, GINEL BACIU ${ }^{14}$ \\ 'University Dunarea de J 0S, Faculty of Medicine and Pharmacy, 47 Domneasca Str., 800008, Galati, Romania \\ ${ }^{2}$ Apollonia University of Iasi, Faculty of Medicine, Academician Ioan Haulica Institute of Researches, 2 Muzicii Str., 700399, Iasi, \\ Romania \\ ${ }^{3}$ Grigore T. Popa University of Medicine and Pharmacy, Faculty of Medicine, 16 Universitatii Str., 700115, lasi, Romania \\ ${ }^{4}$ Sf. Ioan, Emergency Clinical Hospital, 2 Gheorghe Asachi Str., 800494, Galati, Romania \\ ${ }^{5}$ Sf. Maria Clinical Emergency Hospital for Children, 62 Vasile Lupu Str., 700309, lasi, Romania \\ ${ }^{6}$ Sf. Andrei Emergency Clinical Hospital, 177 Brailei Str., 800578, Galati, Romania \\ 7 Elena Doamna Obstetrics and Gynecology Hospital, 29 Elena Doamna Str., 700398, Iasi, Romania \\ ${ }^{8}$ Dr. Iacob Czihac Military Emergency Clinical Hospital, 9 Henri Berthelot, 700483, lasi, Romania \\ ${ }^{9}$ Saarbrucken- Caritasklink St. Theresia University Hospital, 2, D-66113 Saarbrucken, Germany
}

\begin{abstract}
The usual treatment for tuberculosis is difficult by its long-term therapy, raised dosing frequency and adverse effects of anti-tuberculosis drugs. Anionic clays, also called layered double hydroxides are a class of hydrotalcite like structures having high compositional variety and being able to self-assembly in the presence of drug molecules. The work refers to the development of nanohybrid materials like delivery systems that intercalates isonicotinic acid hydrazide, known as isoniazid anti-tuberculosis drug, into layered structure of hydrotalcite compounds. Loaded drug molecules of isoniazid were proved to be released in a controlled way from the as synthesized nanostructure in a simulated buffer solution. The obtained sample was characterized by advanced techniques thus demonstrating the inclusion of isoniazid antibiotic between hydrotalcite sheets. These results revealed important expectations for further researches of these organicinorganic nanocomposites for tuberculosis treatment.
\end{abstract}

Keywords: nanohybrids, tuberculosis, Koch bacillus, infection, newborn, fetus, mother, infant, epidemiology.

One of the most interesting areas of research with importance in medicine is the delivery of therapeutic and active molecules. Conventional therapy has many disadvantages such as rapid release of drug, lack of control over release rate and oscillations in drug levels in the blood stream or other organs of interest, poor water solubility, enzymatic degradation, the use of high drug doses and many adverse effects.

Nowadays, a priority of medical research is the development of efficient drug delivery nanosystems. Therefore, a fascinating progress in science is the designing of nanomaterials possessing various physical and chemical properties at nanolevel, high reactivity and raised specific surface area. Nanohybrids are composite nanomaterials with different features in which one of phases has at least one dimension at nanosize order.

Layered nanohybrids are formed by intercalation of a guest anion into the interlayer space of the inorganic sheets with no change in the pristine layered structure. These organic-inorganic nanohybrid compounds are very ingenious structures that ensure a wide variety of nanocomposites due to the different combination of the inorganic and organic components.

Layered double hydroxides, also known as hydrotalcites, are inorganic materials used as hosts to create diverse organic-inorganic nano-biomaterials which consist of twodimensional thin layers offering extensive uses in various fields [1-5].

In last few years, hydrotalcites appeared as biocompatible drug delivery systems with great features such as cost effective materials, easiness of preparation, possibility of loading various active molecules, release of the drugs in a controlled manner and biodegradability [6$16]$.

Layered double hydroxides (LDHs) are derived from a naturally occurring magnesium hydroxide type brucite being composed of a centering $\mathrm{Mg}^{2+}$ ion between octahedral arranged $\mathrm{HO}$-ions. Each hydroxide ion is bonded to three magnesium atoms.

Their general formula can be expressed $\mathrm{CM}^{2+}$ $\left.\mathrm{M}^{3+}(\mathrm{OH})_{2}\right]^{\mathrm{x}}\left(\mathrm{A}^{\mathrm{n}-}\right) \cdot \mathrm{mH}_{2} \mathrm{O}$, where $\mathrm{M}^{2+}$ representa divalent cation, such as $\mathrm{Mg}^{x / 2+}, \mathrm{Zn}^{2+}, \mathrm{Mn}^{2+}, \mathrm{Ni}^{2+}, \mathrm{Co}^{2+}$, etc., and $\mathrm{M}^{3+}$ represent a trivalent cation, such as $\mathrm{Al}^{3+}, \mathrm{CO}^{3+}, \mathrm{Fe}^{3+}, \mathrm{Cr}^{3+}$, etc., and $A^{n-}$ are exchangeable organic or inorganic anions with charge $\left(\mathrm{n}^{-}\right)$, such as $\mathrm{NO}^{3-}, \mathrm{CO}_{3}{ }^{2-}, \mathrm{Cl}^{-}, \mathrm{SO}_{4}{ }^{2-}, \mathrm{OHO}$, compensating the positive charge of layers due to the isomorphical divalent/trivalent substitution in the interlayer region, while $m$ represents water molecules that are located in the interlayer region (fig. 1) [17].

Hence, LDHs used as drug delivery systems can protect drugs from physic-chemical and anzymatic degradation releasing the drug at the target site in a controlled manner. These features result in a decrease in therapeutic concentration, frequency of doses, toxicity as well as side effects $[18,19]$.

The synthesis of nanodelivery systems for the treatment of tuberculosis refers to intercalation of isonicotinic acid hydrazide (INH), also called isoniazid, into interlayer space of hydrotalcites.

Isoniazid belongs to the drugs group called antitubercular agents being a prescription medication to present and to treat tuberculosis. INH is one of the strongest anti- 

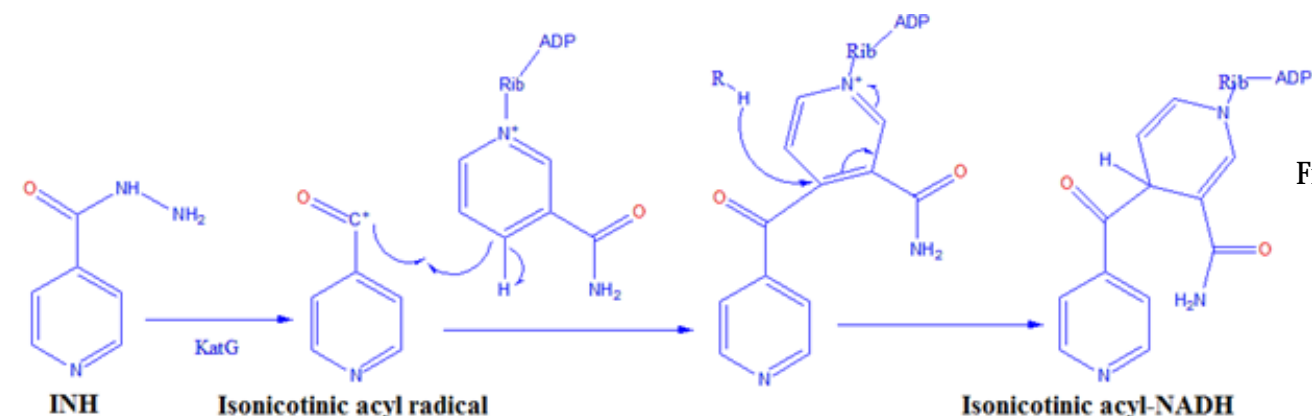

Isonicotinic acyl-NADH

Fig. 1. Mechanism of isoniazid action

tuberculosis drug along with other three drugs namely rifampin, etambutol and pirazinamide.

Pulmonary tuberculosis (TB) is caused by Mycobacterium tuberculosis (discovered by Robert Koch in 1882) when the bacterium infects the lungs, and extrapulmonary tuberculosis where the microb infects other organs such as the tonsils, liver, spleen, kidneys, intestine, bones and brain. The most common challenge in the treatment of tuberculosis is patient non-compliance due to long treatment period, side effects of antituberculosis drugs, multidrug prescriptions, and frequent dosage. For centuries tuberculosis has been a threat to human beings. In last few years, there were approximately 8.6 million people infected with this disease and the latest global tuberculosis report claims that and about 1.3 million died brcause this illness [20-22]. There are studies revealing that this pathogen was able to adapt to migration of humans population from one continent to another reflecting a stable association between host population and specific M.Tuberculosis kinds and social interactions formed by shared geographic and cultural histories. The decrease in the epidemic in last century has been accomplished by improving living standards as well as the antibiotics therapy $[23,24]$.

An important issue of this drug is represented by the adverse effects most commonly including tingling of hands and feet, nausea, vomiting, diarrhea and increased blood levels of liver enzymes. Alcohol consumption may also increase the risk of liver damage during INH treatment.

Till now is not clear if isoniazid harms the unborn baby during pregnancy but it is preferable to avoid isoniazid treatment knowing that any active molecule drug may harm the fetus or excreted in human breast milk and affect the newborn.

All these side effects limit drug dosage thus enhancing the possibility of developing drug resistance [25-30].

Isoniazid mechanism of action is presented in figure 1. For human organism this drug is actually a prodrug activated by bacterial catalase-peroxidase enzyme in $M$. Tuberculosis which catalyse the formation of isonicotinic acyl radical. This product spontaneously connects with $\mathrm{NADH}$ forming nicotinoyl-NAD adduct then continues a process consisting of inhibiting the synthesis of essential components of the mycobacterial cell wall.

Among other radicals, nitric oxide is produced by activation of catalase-peroxidase enzyme being important in the activity of pretomanid, an experimental antituberculosis prodrug [31-33].

The evolution of drug resistance mycobacteria was relatively slow compared to other bacteria pathogens. Multidrug-resistant tuberculosis implies prolonged treatment with toxic drugs although treatment failure is common [34].

There is why numerous studies had focused on obtaining drug delivery systems in order to enhance the efficacy of anti-tuberculosis therapy. This study reports the synthesis and characterization of a nanodelivery system based on layered double hydroxides for the treatment of tuberculosis by the intercalation of isoniazid into the ZnAILDHs structure.

\section{Experimental part}

Materials and methods

ZnAlLDHs-isoniazid nanocomposite by coprecipitation method

Synthesis of ZnAlLDHs-isoniazid nanohybrid, denoted as ZnAILDHs-INH1, was prepared using coprecipitation method. A solution containing zinc and aluminium nitrate salts in a ratio of 2:1 in $50 \mathrm{~mL}$ water was prepared and vigorouslystirred for 20 min under continuous nitrogen flow. Over this solution was added $50 \mathrm{~mL}$ of a $1 \mathrm{~mol} / \mathrm{mL}$ isoniazid solution and stoutly stirred for $20 \mathrm{~min}$ more. The obtained sample was aged at $65^{\circ} \mathrm{C}$ for $48 \mathrm{~h}$, centrifuged and completely washed with deionized water. Then the sample was dried in an oven at $65^{\circ} \mathrm{C}$ for 2 days and ground into a fine white powder being afterwards subjected to characterization.

\section{ZnAlLDHs-isoniazid nanocomposite using ion-exchange route}

Sample preparation by ion exchange, termed as ZnAlLDHs-INH2, was performed using salt solutions of $\mathrm{Zn}^{2+} / \mathrm{Al}^{3+}$ at a molar ratio of 3:1 in $25 \mathrm{~mL}$ water, stirred for $20 \mathrm{~min}$ and then added dropwise to other $25 \mathrm{~mL}$ water maintaining the $\mathrm{pH}$ of a 7.5 value by simultaneous addition of $0.5 \mathrm{M} \mathrm{NaOH}$ solution.

Next step consisted of dropwise adding $100 \mathrm{~mL}$ of a $1 \mathrm{M}$ isoniazid solution to the freshly prepared ZnAlLDHs under a continuous flow of nitrogen. Then, the sample was stirred for $24 \mathrm{~h}$ at $40^{\circ} \mathrm{C}$ and aged for $48 \mathrm{~h}$ at $70^{\circ} \mathrm{C}$. The obtained product was centrifuged, washed with deionized water and dried at $65^{\circ} \mathrm{C}$ for 2 days. The dried sample was ground into a powder for further structural and morphological characterizations.

\section{Results and discussions}

\section{$X R D$ characterization}

X-Ray Diffractometer was used to record XRD patterns of nanocomposites prepared by coprecipitation and ion exchange and the isoniazid sample molecule drug, respectively, presented in figure 2 . Basal spacing of the ZnALLDHs intercalated with nitrate ions between sheets was $8.8 \AA$. For nanocomposites, XRD peaks show that the basal spacing was $12.01 \AA$ and $11.54 \AA$ being first reflection (003) for both ZnAILDHs-INH1 and ZnAlLDHs-INH2 nanohybrids. This increased basal spacing denoted a well intercalation of isoniazid into the interlayer space of ZnALLDHs. The other reflections (006) and (009) are present for both nanocomposites indicating a high crystalinity of the synthesized samples.

The presence of carbonate ions intercalation are reflected by very low intensity peak with basal spacing of approximately $7.5 \AA$ suggesting a common phenomena in layered double hydroxides. 

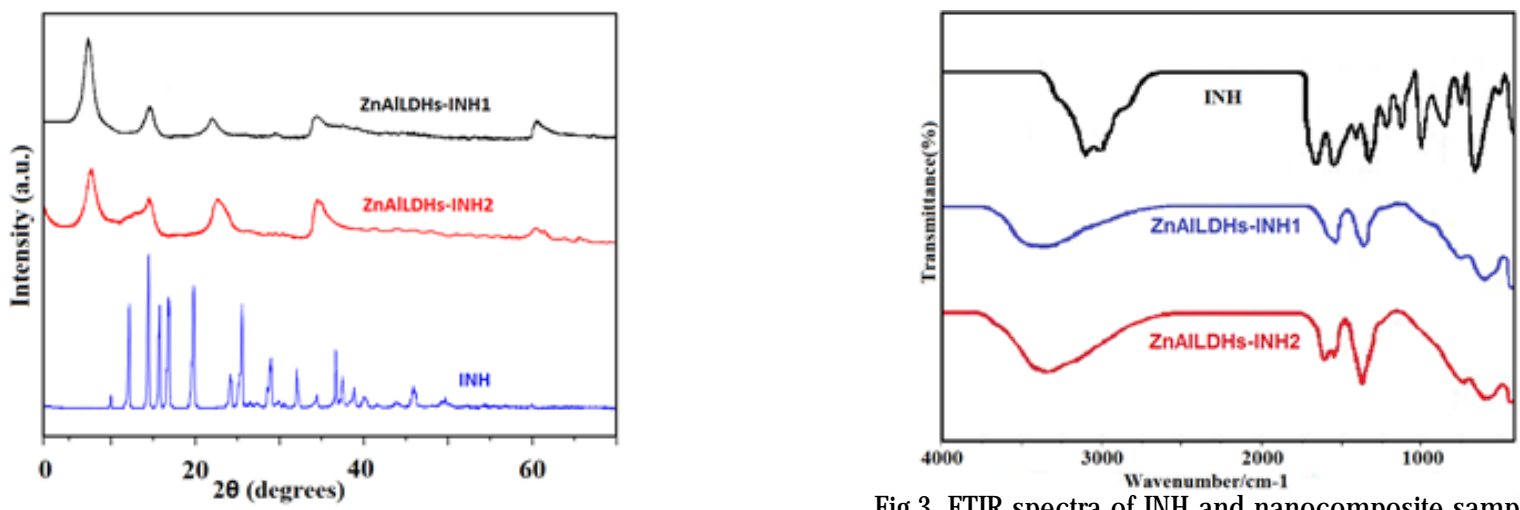

Fig.2. XRD pattern for isoniazid and the nanocomposite samples

Fig.3. FTIR spectra of INH and nanocomposite samples

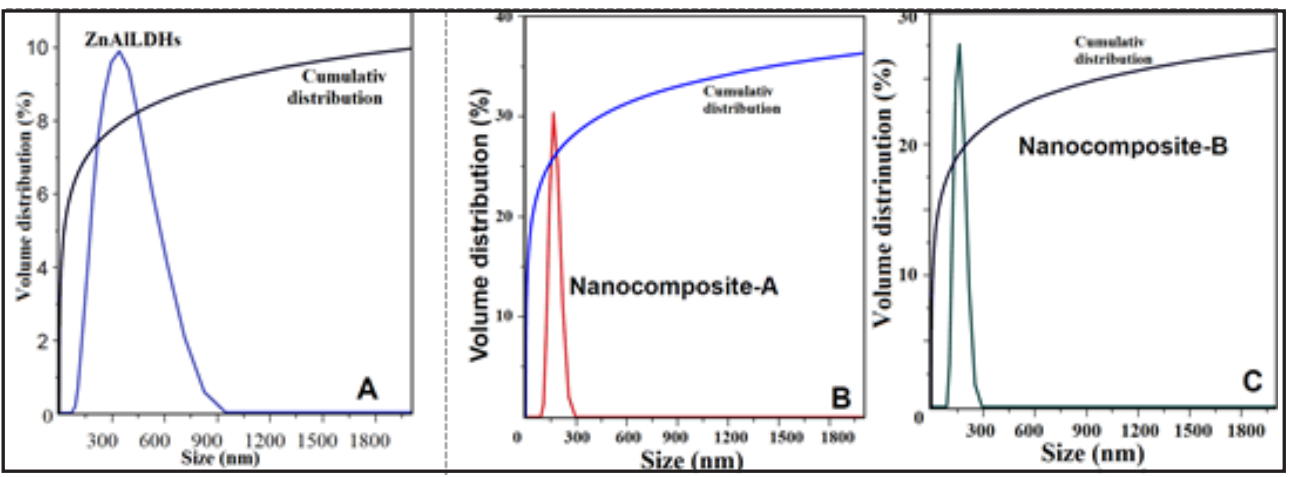

Fig.4. Hydrodynamic size of

ZnAlLDHs and nanocomposite samples

\section{FTIR spectroscopy}

IR spectra of ZnAILDHs-INH1 and ZnALLDHs-INH2 nanocomposites and also of isoniazid are presented in figure 3. FTIR spectrum of pure isoniazid drug reveals several of the particularity functional group bands where the main bands are the carbonyl $\mathrm{C}=\mathrm{O}$, amino $\mathrm{NH} 2, \mathrm{~N}-\mathrm{N}$ single bond, $\mathrm{C}-\mathrm{H}$ bond of the aromatic ring and $\mathrm{C}=\mathrm{C}$ double bond.

Layered double hydroxides have characteristic IR bands from 3.000 to $3.400 \mathrm{~cm}^{-1}$ due to the $-\mathrm{OH}$ vibration and the interlayer water molecules. Nanohybrid samples contain almost all of the bands of the isoniazid and LDHs with a minor change in the wave numbers of particular peaks due to the interaction of the drug with the inorganic matrix.

This kind of shift can be observed for carbonyl band which is shifted from $1650 \mathrm{~cm}^{-1}$ to $1600 \mathrm{~cm}^{-1}$ in both nanohybrid samples. FTIR peaks contain N-N stretching vibration because of the terminal amine group of the drug. It is remarkable that the presence of the characteristics bands of isoniazid in the IR spectra of nanohybrids supports the XRD pattern, thus demonstrating the successful intercalation of the drug between the interlayer space of the ZnAlLDHs.

\section{Analysis of particle size}

Particle size of the simple ZnAlLDHs and the two nanocomposites (presented in fig. 4) was determined using a dynamic light scattering technique by a zeta sizer. The procedure consisted of sample dispersion in deionized water followed by sonication and finally the analysis using a zeta sizer. ZNAILDHs sample had a wide distribution of sizes being ranged from 50 to $900 \mathrm{~nm}$.

In compliance with the cumulative distribution frequency, almost $85 \%$ of particles were equal to or less than the $340 \mathrm{~nm}$. Particle size of the two nanohybrid samples was distributed over a narrow scale of $50-300 \mathrm{~nm}$ and almost $70 \%$ of the particles had the size equal to or less than $165 \mathrm{~nm}$.

\section{Release characteristics of drug}

Release profile of the drug from nanobybrid samples (not shown) was performed in human body simulated physiological phosphate buffer solution of $\mathrm{pH} 7.4$ simulated to blood $\mathrm{pH}$ and $\mathrm{pH} 4.8$ simulated to intracellular liposomal $\mathrm{pH}$. The difference in the release features, faster al $\mathrm{pH}$ of 4.8 and more sustained at $p \mathrm{H}$ of 7.4 was due to the release mechanism since in acidic condition the drug was released by ion exchange and degradation, whereas in alkaline condition the release was accomplished byion exchange.

\section{Conclusions}

Novel nanomaterial was designed by exploring its properties at nanoscale and further used as efficient device in pharmaceutical field. This behavior has no significant effect on their layered structure or activity in medical area as drug delivery nanosystems.

This study focused on applications of hydrotalcites in biomedicine due to their physic-chemical stability, high biocompatibility and low toxicity acting as good candidates for isoniazid delivery.

These nanohybrids are able to increase the therapeutic effect of anti-tuberculosis drug being a huge step towards developing antimicrobial agents with increased activity on pathogens.

The release of isonicotinic acid hydrazide from the nanoformulation was performed in a simulated human phosphate buffer solution.

By shortening therapy period and limiting side effects can be improved the compliance of patients to the tuberculosis treatment.

\section{References}

1. SAMPATH KUMAR, K., BHOW MIK, D., CHIRANJIB, B., CHANDIRA, M., TRIPATHI, K.K., J. Chem. Pharm. Res. 2, 2010, p. 349.

2. TRIKERIOTIS, M., GHANOTAKIS, D.F,. Int. J. Pharm., 332, 2007, p. 176.

3. YANG, Q.Z., YANG, J ., ZHANG, C.K., Int. J. Pharm., 326, 2006, p. 148. 
4. MANGIACAPRA, P., RAIMONDO, M., TAMMARO, L., VITTORIA, V., MALINCONICO, M., LAURIENZO, P., Biomacromolecules, 8, 2007, p. 773.

5. ALBERTI, G., CONSTANTINO, U., Comprehensive Supramolecular Chemistry: Solid-State Supramolecular Chemistry: Two- and ThreeDimensional Inorganic Networks; ALBERTI, G., BEIN, T., Eds; Pergamon-Elsevier: Oxford, UK, 7, 1996, p. 1.

6. ARBUNE, M., DECUSARA, M., MACOVEI, L.A., ROMILA, A., IANCU, A.V., INDREI, L.L., PAVEL, L., RAFTU, G., Rev. Chim. (Bucharest), 69, no. 3,2018, p. 1240.

7. CRETEANU, A., OCHIUZ, L., VIERIU, M., TANTARU, G., MedicalSurgical J ournal (Revista Medico-Chirurgicala), 122, no. 4, 2018, p. 840.

8. NOVAC, O., BARBACARIU, L., SLANINA, A.M., FRASINARIU, O.E., TRANDAFIR, L.M., Medical-Surgical Journal (Revista MedicoChirurgicala), 122, no. 4, 2018, p. 689.

9. CLEMENS, D.L., LEE, B.Y., XUE, M., THOMAS, C.R., MENG, H., FERRIS, D., NEL, A.E., ZINK, J.I., HORWITZ, M.A., Antimicrob Agents Chemother., 56, no. 5, 2012, p. 2535.

10. SAIFULLAH, B., HUSSEIN, M.Z., HUSSEIN-AL-ALI, S.H., ARULSELVAN, P., FAKURAZI, S., Drug Des Devel Ther., 7, 2013, p. 1365.

11. DEL, HOYO, C., Appl Clay Sci., 36, no. 1-3, 2007, p. 103.

12. CRETEANU, A., OCHIUZ, L., VASILE, C., VIERIU, M., TANTARU, G., Farmacia, 65, no. 4, 2017, p. 545.

13. TRANDAFIR, L.M., BACIU, G., CONSTANTIN, M.M.L., MASTALERU, A., TEMNEANU, O.R., MIHAI, B., NOVAC, O., FRASINARIU, O.E., IVAN, A., TUDORACHI, N.B., Rev. Chim. (Bucharest), 69, no. 11, 2018, p. 3048.

14. TANTARU, G., MARIN, L., VIERIU, M., PANAINTE, A.D., POIATA, A., APOSTU, M., BIBIRE, N., Rev. Chim. (Bucharest), 66, no. 12, 2015, p. 1965.

15. CALIN, A.M., DEBITA, M., DRAGOMIR, R., STEFANESCU, O.M., BUDACU, C., SZALONTAY, A.S., Rev Chim (Bucharest), 68, no.11, 2017, p. 2618.

16. TANTARU, G., APOSTU, M., Rev. Chim. (Bucharest), 61, no.7, 2010, p. 632.

17. CAVANI, F., TRIFIRO, F., VACCARI A., Catal Today., 11, no. 2, 1991, p. 173.

18. DUCEAC, L.D, DOBRE, C.E., PAVALEANU, I., CALIN, G., NICHITUS, S., DAMIR, D., Rev. Chim. (Bucharest), 68, no. 1, 2017, p. 168.
19. DUCEAC, L.D., STAFIE, L., BANU, E.A., PADURARU, O., CALIN, G., CIUHODARU, M. I., Rev. Chim. (Bucharest) , 68, no 11, 2017, p. 2542. 20. SHARMA, S.K., MOHAN, A., Indian J Med Res., 120, no. 4, 2004, p. 316.

21. SUMARTOJ O, E., Am Rev RespirDis., 147, no. 5, 1993, p. 1311.

22. *** WORLD HEALTH ORGANIZATION. Global tuberculosis report 2013. WHO Press, World Health Organization, 20 Avenue Appia, 1211 Geneva 27, Switzerland. 2013.

23. GAGNEUX, S., DERIEMER, K., VAN, T., KATO-MAEDA, M., DE JONG, B.C., NARAYANAN, S., NICOL, M., NIEMANN, S., KREMER, K., GUTIERREZ, M.C., HILTY, M., HOPEWELL, P.C., SMALL P.M., Proceedings of the National Academy of Sciences of the United States of America, 103, no. 8, 2006, p. 2869.

24. HIRSH, A.E., TSOLAKI, A.G., DERIEMER, K., FELDMAN, M.W., SMALL, P.M., Proceedings of the National Academy of Sciences of the United States of America, 101, no. 14, 2004, p. 4871.

25. SAIFULLAH, B., HUSSEIN, M.Z., HUSSEIN, AL-ALI S.H., In J. nanomedicine, 7, 2012, p. 5451.

26.REUBEN, G., CHRISTOPHER, A., CHRISTIAN, G., HAILEYESUS, G., PHOEBE, W., BRIAN, W., CID, 50, no. 3, 2010, p. 215.

27.RAMAPPA, V., AITHAL, G.P.,. JCEH., 3, no. 1, 2013, p. 37.

28.VIDRIO, H., MEDINA, M., FERNÁNDEZ, G., LORENZANA-JIMÉNEZ, M, CAMPOS, A,E., Gen Pharmacol-vasc S., 35, no. 4, 2000, p. 195. 29.SCHABERG, T.K.R., LODE, H., Eur Respir J., 9, 1996, p. 2026.

30. ELENA, ARIELA, B., AUREL, N., EVA, MARIA, E.C., GINEL, B., ALINA M., LILIANA, C., Archives of Medical Science. DOI: https://doi.org/ 10.5114/aoms.2018.78768, 2018, p. 1.

31. SUAREZ, J., RANGUELOVA, K., JARZECKI, A.A., MANZEROVA, J., KRYMOV, V., ZHAO, X., YU, S., METLITSKY, L., GERFEN, G.J., MAGLIOZZO, R.S., The J ournal of Biological Chemistry, 284, no. 11, 2009, p. 7017.

32. TIMMINS, G.S., MASTER, S, RUSNAK, F., DERETIC, V., (Antimicrobial Agents and Chemotherapy, 48, no. 8, 2004, p. 3006.

33. AHMAD, Z., KLINKENBERG, L.G., PINN, M.L., FRAIG, M.M., PELOQUIN, C.A., BISHAI, W.R., NUERMBERGER, E.L., GROSSET, J.H., KARAKOUSIS, P.C., The Journal of Infectious Diseases., 200, no. 7, 2009, p. 1136.

34. ELDHOLM, V., BALLOUX, F., Trends in Microbiology., 24, no. 8, 2016, p. 637.

Manuscript received: 14.02 .2019 